\title{
PÁROS ÖSSZEHASONLÍTÁSOK A DÖNTÉSHOZATALBAN
}

\author{
TEMESI JÓZSEF
}

\begin{abstract}
A döntéselméleti alkalmazások egyik kiemelt területe a többtényezős döntéshozatal. Ebben a modellben véges sok alternatívát véges sok tényező szerint értékelve egy döntési mátrix elemzése, az esetek többségében egy alternatíva rangsor felállítása, vagy a legjobb alternatíva megtalálása a feladat. Ez a tanulmány - a szerző kutatásainak tükrében - a döntési mátrix előállításának egyik népszerű technikájával, a páros összehasonlítások módszerével foglalkozik. A rövid cikk keretében a speciális döntési probléma tulajdonságainak bemutatását követően az alkalmazás feltételeinek megvilágítása a cél, azt hangsúlyozva, hogy valós döntési feladatok megoldásakor és az eredmények értelmezésekor a páros összehasonlítások módszerének előnyeit és hátrányait egyaránt figyelembe kell venni, és ajánlatos a döntéshozó bevonása a megoldási folyamatba.
\end{abstract}

\section{Bevezetés}

A 2019-ben Szegeden rendezett XXXIII. Magyar Operációkutatási Konferencián ért az a nagy megtiszteltetés, hogy a Magyar Operációkutatási Társaság (MOT) Egerváry Jenő emlékplakettjét átvehettem. Ez a rövid cikk a díjazottak számára indított sorozatban az Alkalmazott Matematikai Lapok felkérésére készült és pályám néhány jellemző vonásáról, illetve döntéselméleti kutatásaim egyik fontos eszközéről, a páros összehasonlítási mátrixokról szól. Engedtessék meg, hogy eközben ennek a folyóiratnak a nevében szereplő első jelzőre koncentráljak.

A díj apropóját felhasználva elöljáróban mindenképpen el kell mondanom, hogy a MOT az elmúlt 30 évben számomra kiemelkedően fontos hazai szakmai terepet jelentett és sok kiváló kollégával dolgozhattam együtt, akik nem csak a társaságban, hanem az MTA Operációkutatási Bizottságában is sikeresen képviselik az operációkutatást. Különösen emlékezetes számomra az évszázad első évtizede, amely a nagy sikerü budapesti EURO 2000 konferenciával indult, és amikor a továbbiakban elnökségi tagként, majd a MOT elnökeként tevékenykedhettem. 


\section{Pályámról röviden}

Az akkor még Marx Károly nevét viselő Közgazdaságtudományi Egyetemen végeztem 1974-ben, a terv-matematika szak utódaként létrejött népgazdasági tervezés szak gazdaságmatematikai szakágazatán. Sok kiváló tanár tanította a matematika közgazdasági alkalmazásai iránt érdeklődő csoportot, sajnos közülük Bod Péter, Krekó Béla, Szép Jenő, Ziermann Margit már nincs az élők sorában.

Az 1968-ban elindított úgynevezett új gazdasági mechanizmus egyik következménye az volt, hogy megnőtt az érdeklődés a makrogazdasági döntésekben felhasználható matematikai eszközök iránt. A gazdasági tervezésben a matematikai programozás kiemelt szerepet kapott, elméleti és gyakorlati szakemberek kezdtek el foglalkozni elsősorban a lineáris programozási modellekkel, s mind a Tervhivatalban, mind az egyetemeken megjelentek az ezeket a modelleket oktató tantárgyak. Virágzó korszaka volt ez az időszak az operációkutatási modellezésnek: szakkönyvek, tudományos cikkek fémjelezték azt a vonulatot, amelyben a magyar operációkutatók is nemzetközileg elismert eredményeket tudtak felmutatni. Ez a háttér vonzott engem is a matematikailag izgalmas, számítástechnikailag robbanásszerüen fejlődő, hasznos alkalmazásokkal kecsegtető terület felé.

Halpern Lászlóval, csoporttársammal, izgalmasnak találtuk az árnyékárak elemzését, ebből a témából írtunk díjnyertes TDK-dolgozatot. Varga József volt a Közgázon az akkori Matematikai Tanszéken az LP-modellek egyik szakavatott alkalmazója, ő volt a témavezetője ezen modellek népgazdasági tervezésbeli alkalmazásáról szóló szakdolgozatomnak. Végzés után a tanszékre kerülve folytattam a gyakorlati munkákat (a valós problémák megoldásának igénye végigkísérte további pályámat), majd Gáspár Lászlóval azt a „piaci rést” találtuk meg, amelyet a didaktikus, példákkal dúsan ellátott, ugyanakkor matematikailag precíz tárgyalású egyetemi tankönyvek jelentettek: így születtek meg a Lineáris programozási és Matematikai programozási gyakorlatok címü könyvek az 1980-as évek második felében [12], [13] - ezek a könyvek még ma is népszerüek az egyetemi oktatásban. (Hasonlóképpen, a Varró Zoltánnal 2007-ben írt Operációkutatás könyvünk [22] is fóleg az egyetemi oktatás céljait tartja szem előtt.) Az 1970-es évek végén, az 1980-as évek elején - miközben ma már elképzelhetetlenül sok ágazati és vállalati alkalmazási feladatban szerezhettem tapasztalatot a gyakorlati feladatok megoldásának szépségeit és buktatóit illetően - egyre inkább a döntéselmélet vált szükebb szakterületemmé, azon belül is a többcélú döntések módszertana.

A rendszerváltás utáni mintegy 15 évben párhuzamosan futott egyetemi vezetői és szakmai életutam. A sokféle néven müködő Közgazdaságtudományi Egyetem dékánjaként, rektorhelyetteseként oktatási és tudományos ügyekkel foglalkoztam. Fontos vívmánynak tartom, hogy eközben - Zalai Ernővel, Forgó Ferenccel, Rapcsák Tamással és más kiváló kollégákkal együtt sikerült megőrizni, sőt, a 2000es évek elején újraéleszteni tárgyakat és szakokat az igényes matematikai közgazdaságtani, operációkutatási képzések vonalán. 2000-től 2014-ig tanszékvezetőként is igyekeztem ezeket védeni, fejleszteni. 
Jelentősebb hazai és külföldi publikációim először az operációkutatási alkalmazások területén jelentek meg. Tudom, hogy a tudományos közvélemény ambivalensen viszonyul a társszerzős müvekhez, én azonban kimondottam hasznosnak tartottam a közös munkát és büszke vagyok arra, hogy Forgó Ferenccel, Stahl Jánossal, Pór Andrással, Rapcsák Tamással, Fülöp Jánossal dolgoztam együtt és publikáltuk eredményeinket [10], [15], [14], [11]. 2002-ben, a döntéselméleti kurzusaim számára kidolgozott tananyag szakkönyvként is megjelent [18], és a szakma által elismert nemzetközi folyóiratokban publikált egyes döntéselméleti témájú cikkeket már olyan tanítványaimmal közösen írtuk (pl. [1], [2]), akik ebből a könyvből ismerték meg az alapfogalmakat. Bozóki Sándor és Csató László az utóbbi években már egyenrangú kutatóként, szakmai díjak birtokosaként önálló, eredményes tudományos pályát futnak be. Legutóbbi OTKA kutatásunk esetében Bozóki Sándor átvette tőlem a kutatásvezetői pozíciót is, eredményei nagyszámú hivatkozást generálnak. Csató László a közösen írt sport témájú cikk mellett számos alkalmazási és elméleti cikkel vesz részt a közös munkában.

Talán az eddigiekből is látható, hogy számomra a tudományos munka nem

magányos elmélkedést, hanem együttműködést, mühelymunkát jelent. Így nem véletlen, hogy a szakmai társaságokban is aktív szerepet vállaltam és a MOTon kívül a Gazdaságmodellezési Társaságnak is voltam elnökségi tagja és elnöke. Külön örülök annak, hogy a Rapcsák Tamás-díj kuratóriumának tagjaként szerepem lehet abban, hogy a névadóhoz méltó kollégák nyerjék el ezt a kitüntetést. Nemzetközi szerepléseim elsősorban a nemzetközi operációkutatási társaságok és az MCDM (Multi-Criteria Decision Making) Society, a Decision Science Institute és az International Society of Analytic Hierarchy Process konferenciáihoz kötődnek. Fulbright-ösztöndíjasként a New Hampshire University döntési tanszékén oktattam és kutattam.

\section{Páros összehasonlításokról alkalmazói szemléletben}

Kutatói pályám elején két olyan részterület ragadott meg, amelyek mindmáig hatással vannak tudományos munkámra és annak szemléletére. Nagyobb méretü, valós alkalmazások során a megbízókkal, azaz egy-egy döntési feladat gazdáival való munka során legtöbbször az derült ki, hogy a matematikai programozási feladat keretrendszerében (feltételek és célfüggvény) megoldott optimalizálási probléma eredménye nehezen vezethető be a gyakorlatban - például egy termelési feladatban túlságosan kevés termék kapott pozitív értéket vagy kapacitáskihasználatlanságok keletkeztek. Modellezési ügyeskedéssel ez ugyan elkerülhetővé vált, de az így bővülő feltételi rendszerben az eredmény túlságosan „irányítottá" válhatott, vagy akár az is könnyen előfordulhatott, hogy nincs megengedett megoldás. Életszerűbb szemléletet jelentett, ha a közgazdaságtan egyik fontos fogalmát, a Pareto-optimalitást felhasználva nem egyetlen célfüggvény szerint keressük a legjobb megoldást. Ez egybevágott a gazdasági döntések elméleti konstrukcióiban 
is tért hódító új irányzattal, miszerint a gazdasági szereplőket nem egyetlen cél (pl. a profitmaximalizálás) vezérli, hanem egymással versengő, ellentétes hatású célok együttesét kell kezelni. A vektormaximum-probléma (a kezdetekről lásd például Steuer könyvét [17]) hasznos modellezési eszköznek látszott mind a makroökonómiai modellezésben, mind a vállalati modellezésben:

$$
\max \mathbf{f}(\mathbf{x}), \quad \mathbf{x} \in X, \quad \text { ahol } \quad X \subseteq R^{n}, \quad \text { és } \quad f: X \rightarrow R^{k}
$$

Az (1)-ben szereplő feladat megoldását azok az efficiensnek nevezett $\mathbf{x}^{*} \in X$ $n$-dimenziós pontok jelentik, amelyek esetében nem találunk olyan $\mathbf{x} \in X$ vektort, amelyre $\mathbf{f}(\mathbf{x}) \geq \mathbf{f}\left(\mathbf{x}^{*}\right)$, és $\mathbf{f}(\mathbf{x}) \neq \mathbf{f}\left(\mathbf{x}^{*}\right)$ teljesül. Döntéshozói szemmel a $Q=\mathbf{f}(X)$ $k$-dimenziós kimeneti pontok azon $\mathbf{q}^{*} \in Q$ nem-dominált (Pareto-optimális) vektorait keressük, amelyekhez nem található olyan $\mathbf{q} \in Q, \operatorname{hogy} \mathbf{q} \geq \mathbf{q}^{*}$ és $\mathbf{q} \neq \mathbf{q}^{*}$. Valós alkalmazásokban sajnos a feladat megoldása nehezen tárható a döntéshozók elé, mert az efficiens pontok halmaza általában végtelen számosságú. Ha le tudjuk írni a hatékony felületet (ez még a lineáris esetben sem könnyü feladat, lásd Yu és Zeleny [24] cikkét), a döntéshozó továbbra is azzal a kérdéssel szembesül, hogyan lehet ezek közül választani. Sőt, választását még az is nehezíti, hogy a

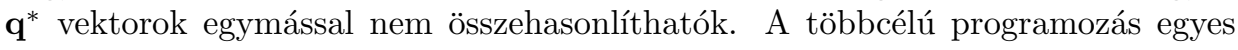
módszerei ezért nem is a teljes efficiens halmaz leírását célozzák meg, hanem azok közül egyetlen pont kiválasztására koncentrálnak: egy olyan pontra, amely egy elfogadható döntési elvet követve automatikusan juttat el a feladat megoldásához. E módszerek alapos összefoglalása található Ehrgott [9] könyvében. Ha például elfogadjuk azt az elvet, hogy az egyedi célfüggvények optimumához legközelebb eső efficiens pontot választjuk, akkor a kompromisszum-programozás alkalmazása automatikusan megadhatja a döntési feladatként tekintett programozási modell egyetlen (alkalmazandó) megoldását. Ez az „automatizmus” tehát kivezet a döntésképtelenséget jelentô végtelen sok optimális megoldás csapdájából, ám - s ez volt, ami engem érdekelt -, mégis egy külső (modellen kívüli) elemet hív ehhez segítségül: a döntési elvet. A végső megoldásba vetett hitünket tehát egy-egy ilyen feladatnál aláássa az, hogy több, nem ugyanahhoz a Pareto-optimális ponthoz vezető döntési elv létezik - annyi történt tehát, hogy új feladatként a döntési elvek között kell választanunk.

Tegyük fel viszont, hogy valamilyen axiómarendszer elvezet bennünket oda, hogy a legjobb kompromisszum fentebb felvázolt megoldását tekintjük az egyetlen megfelelő döntési elvnek. Kimutatható, hogy ebben az esetben sem dőlhetünk hátra: most a távolság-fogalmak közül kell választanunk, hiszen például az ún. ideális ponthoz legközelebbi Pareto-optimális pont függ az alkalmazott távolságfogalomtól [23]. Az én alkalmazói megközelítésem számára is csábító lehetett volna az, hogy valamelyik automatikus módszer mellett érveljek, ezzel előállítva a döntési feladat egyetlen megoldását, ám tapasztalatom szerint ennél megfelelőbb eljárás is található akkor, ha a döntéshozó a megoldás valamely fázisában (vagy végig) rendelkezésre áll: tőle kell azt a „külső információt” beszerezni, amelyik nélkül 
a megoldás nem redukálható egyetlen Pareto-optimális pontra. Ehhez interaktív módszereket javasoltam, vagyis a döntéshozó bekapcsolását a megoldási folyamatba.

Az (1) vektormaximum probléma mellett figyelmem arra a rokon feladatra irányult, amelyiket nem végtelen sok, hanem véges sok, egymással össze nem hasonlítható vektorként írhatunk le. A többtényezős döntési feladatok szokásos megfogalmazásában véges sok alternatíva közül kell választanunk véges sok tényező kvantitatív vagy kvalitatív értékelései alapján, ahol adott az, hogy egy-egy szempont esetében a nagyobb érték jobbat vagy kevésbé jobbat jelent. Legyenek a többtényezős döntési probléma kritériumai $C_{1}, C_{2}, \ldots, C_{k}$, az alternatívák pedig $P_{1}, P_{2}, \ldots, P_{n}$. Az alternatívákat minden kritérium szerint páronként összehasonlítjuk egymással. Ezáltal a feladat lényegi része egy $\mathbf{D}$ döntési mátrixként jeleníthető meg. Nyilvánvaló, hogy a $\mathbf{D}$ mátrix tekinthető úgy is, mintha a vektormaximum-probléma Pareto-optimális pontjaiból véges sokat választottunk volna ki, azaz a döntési elvek megfelelően módosított változatai átvihetőek lehetnek a többtényezős feladatra is. Valóban, például a kompromisszum-technika itt is alkalmazható, ha például ideális megoldásként az egyes tényezők legjobb értékeit választjuk. A többtényezős feladatra ettől eltérő, egyéb megoldás-koncepciók is megjelentek (ezekkel a [18] könyvemben részletesen foglalkoztam).

A véges feladat viszont az esetek többségében azért követel meg a folytonos esettől eltérő szemléletet, mert a vektorok éppen hogy nem állnak készen egy többcélú programozási feladat Pareto-optimális felületéről történő leválogatás után, hanem a tényezők szerinti értékelések előállítása is szerves része az eljárásnak. Mivel az ilyen típusú feladatoknál sürün előfordul, hogy az értékelések a döntéshozónak az alternatívákra vonatkozó preferenciáinak számszerü kifejezését jelentik az egyes tényezők szerint, megfelelő skálát választva ez az értékelés könnyen véghez vihető akár egyszerre, akár az alternatívák párjaira. Saaty javaslata volt az [16], hogy a páros összehasonlítás technikáját kell használni. Saaty úgy érvelt, hogy ha az értékelendő alternatívák száma aránylag nagy, akkor a direkt értékelés nehéz és a döntéselméleti irodalomban tárgyalt szisztematikus torzítások megjelenésének veszélyét hordozza magában. Arányskála alkalmazása esetében viszont a páronkénti összehasonlítások a döntéshozó számára egyszerüek és könnyen átgondolhatók (hányszor jobb az egyik alternatíva a másiknál az adott szempont szerint?).

$\mathrm{Az} \quad \mathbf{A}_{m}$ páros összehasonlítási mátrix $a_{i j m}$ eleme jelentse az $i$-edik és a j-edik alternatíva összehasonlításának eredményét az $m$-edik kritérium szerint $(m=1, \ldots, k)$. Elhagyva a kritérium szerinti indexet, koncentráljunk a döntéshozó által megadott valamely $\mathbf{A}$ mátrixra. Legyen a feladat a $w_{1}, w_{2}, \ldots, w_{n}$ implicit súlyok meghatározása az $a_{i j}$ értékeinek segítségével, amelyeket a $w i / w j$ hányadosok becsléseinek tekintünk. Ezek a következő tulajdonságokkal rendelkeznek: 


$$
\begin{aligned}
& a_{i j}>0 \quad \text { és } \quad a_{i i}=1,(i, j=1, \ldots, n) \text { pozitivitás, } \\
& a_{i j}=1 / a_{j i}, \quad(i, j=1, \ldots, n) \text { reciprocitás. }
\end{aligned}
$$

Ha ez a pozitív, reciprok mátrix még a

$$
a_{i j} a_{j k}=a_{i k}(i, j, k=1, \ldots, n)
$$

tulajdonsággal is rendelkezik, akkor az A mátrixot konzisztensnek nevezzük. Könnyen belátható, hogy a konzisztens esetben a w vektor előállítása többféle egyszerü módon konstanstól eltekintve egyértelmüen elvégezhetö, a konstans pedig abból kapható, hogy az elemek összege 1. Ez az ideális eset ritkán fordul elö, a valóságban ezek az értékek eltérnek a pontos preferencia-hányadosoktól. Saaty felismerése az volt, hogy a páros összehasonlítások mátrixából a valós preferenciák sajátvektor módszerrel jól becsülhetők.

Lassan negyven éve, hogy ez a módszer az alternatívák hierarchikus csoportosításával kiegészítve az Analytic Hierarchy Process (AHP) elnevezést kapta. Az alkalmazók körében rendkívül népszerü lett, viszont több pontban is viták lángoltak fel körülötte. Nem kívánok ezeknek a többfelé elágazó vitáknak a részleteibe belemenni (jó összefoglalást ad például Brunelli [7]). Érdemes azonban megemlíteni, hogy a felmerülő problémakörök tisztázásához az a kutatócsoport, amelyik több OTKA-kutatás keretében az MTA SZTAKI Operációkutatás és Döntési Rendszerek Kutatócsoportjában és a Corvinus Egyetem Operációkutatási Tanszékén dolgozott együtt, fontos eredményekkel járult hozzá. Az alapfeladatnál érdekes kérdés, hogy a becslés milyen módszerekkel végezhető el és ezeknek milyen tulajdonságai vannak. Az egyik legvitatottabb témakör a páros összehasonlítások technikájával készített mátrix inkonzisztenciája, azaz a (iii) tulajdonságtól való eltérés mértéke. A kutatócsoportban erre vonatkozóan publikált eredmények, például [5] és [6] magas idézettségűek. A nem teljes páros összehasonlítási mátrixokra kiterjesztett eredmények és alkalmazás új, eddig feltáratlan területekre vezette a kutatócsoport tagjait [4], [1]. Szépen köti össze a többcélú programozás és a többtényezős döntések világát az utóbbi megoldásainak efficiens voltáról szóló cikk [3].

A részletek taglalása és a megmaradt matematikai jellegű kihívások felsorolása helyett a továbbiakban inkább egy olyan témáról ejtenék szót, amelynek az alkalmazásokkal foglalkozó publikációknál tapasztalt háttérbe szorulása az utóbbi 10 évben több cikk megírására inspirált. Az operációkutatási modellek lényegéhez tartoznak azok a feltételek, amelyek múködésüket és alkalmazásukat lehetővé teszik, ugyanakkor pedig korlátozzák is. A lineáris programozási modelleknél elöfeltétel a változók folytonossága (ez az alkalmazásoknál végtelen oszthatóságot jelent), vagy a linearitás (például az erőforrások felhasználása és a célfüggvény szempontjából). Ha ezek nem teljesülnek, ám a modellt eredeti formájában alkalmazzuk, akkor az eredmények kétesek vagy nehezen magyarázhatók lesznek. 
Egy alkalmazásnak implicit vagy explicit módon tartalmaznia kell a matematikai modellnek az adott problémára vonatkozó érvényességének igazolását, vagy az eredmények ismertetésekor ki kell térnie azokra az elhanyagolásokra, torzításokra, elvonatkoztatásokra, amelyek azok felhasználását árnyalják. Örök alkalmazói dilemma, hogy a modellezés révén kapott megoldás egy az egyben bevezethetö-e (például egy szállítási feladatnál valószínűleg igen, ha nem hanyagoltunk el túl sok tényezőt), vagy csak orientáló jellegü (például egy tömegkiszolgálási modellnél csak a rendszer bővítését alapozza meg, de nem biztos, hogy éppen a modell számszerü eredményének megfelelően). Ha egy többtényezős döntési problémát tekintünk, fokozottan igaz az, hogy körültekintően kell eljárnunk a legjobb megoldást illetően. Mint ebből a rövid gondolatmenetből valószínűleg az operációkutatással foglalkozó kollégák már régen rájöttek, a modellezés validálási szakaszáról beszélek - amelyet sajnálatosan elhanyagolva látok a publikációkban.

A többcélú optimalizálás módszertanával foglalkozva az egyik legfontosabb konklúzióm az volt, hogy a modellt döntési feladatként tekintve a döntéshozó által valóban felhasználható megoldás nem adható pótlólagos információk bevezetése nélkül. Ezek a többlet információk származhatnak közvetlenül a döntéshozótól, ha ő elérhető és bevonható a megoldási eljárásba, de felhasználhatunk magára a döntési feladatra vagy a döntéshozókra általában igaznak tekintett tulajdonságokat is, például axiomatikus vagy implementációs modellkeretben. Természetes volt, hogy a véges feladat esetében is megmaradtam ennél a gondolatmenetnél és a páros összehasonlítási mátrix előállítását interaktív eljárásként kívántam alkalmazni, lehetőleg úgy, hogy egyben a döntési feladat egyetlen megoldása is előálljon [19].

2011-ben megjelent cikkemben [20] a hivatkozások szerint sokak egyetértésével találkozó, míg mások szerint erős megkötést jelentő tulajdonság teljesülését állítottam a páros összehasonlítási eljárást alkalmazók elé, ez a hibamentességi (error-free) tulajdonság. Legegyszerübben ezt úgy fogalmazhatjuk meg, hogy egy páros összehasonlításokat használó eljárás eredménye mindaddig nem tekinthető érvényesnek, míg a becslés alapjául szolgáló alapmátrixot a döntéshozó - az eljárás egészében részt véve, vagy csak az eljárás végén - nem validálta. Amennyiben nem rendelkezünk ilyen döntéshozói „, jóváhagyással”, a mátrix elvileg nem tekinthető megbízhatónak. Ez a megközelítés különösen fontos azoknak a döntési feladatoknak a megoldásakor, amelyek az egyéni preferenciák kinyilvánítására építenek.

Mivel az AHP egyik lényegi vonása a döntéshozó konzekvens válaszai hiányának elismerése - ez a mátrix inkonzisztenciáját jelenti matematikai értelemben -, a szakirodalomban felértékelődtek az inkonzisztens mátrixok korrekcióját elvégző módszerek, s ezzel egyidejüleg magának az inkonzisztenciának a mérésére szolgáló indexek (Brunelli [8] részletes összefoglalását adja a jelenlegi helyzetnek). Ha azonban egy kiinduló mátrix még akkor is lehet hibás, nem megbízható, ha az konzisztens, akkor a korrekciós módszerek (is) csak akkor lehetnek értelmezésemben megfelelőek, ha azok a döntéshozói validáción átestek, vagy ez valamilyen kerülő 
úton biztosítható volt. Ilyen irányban mutatott példát legutóbbi publikációm egy egyszerűbb esetben, amikor a páros összehasonlítási mátrix előállítása a döntéshozó jelenlétében, verbális skálán történik [21].

Kutatócsoportunkban, ahol kiváló matematikusok is dolgoznak a páros összehasonlítási módszertan nyitott kérdéseinek megoldásán, jómagam tehát az utóbbi időben a feladat (jelen esetben a véges többtényezős probléma) döntési oldalának tulajdonságaival, a megoldás érvényességének kérdéseivel foglalkoztam legtöbbet. Izgalmasnak találom azokat a modellezési kérdéseket, amelyek az alkalmazások publikálásakor és az eredmények interpretálásakor felmerülnek, s amelyek egy része a döntési feladat matematikailag egzakt megfogalmazásával és kezelésével együtt a döntéshozót is a megoldási folyamat részének tekinti. Természetesen ez nem minden döntési probléma esetében van így, ám éppen a többtényezős feladatoknál találhatók jellegzetes feladattípusok, ahol ez a kérdésfelvetés nem hárítható el. Remélem, hogy az Alkalmazott Matematikai Lapok olvasóinak sem idegen ez a megközelítés, ezért mertem ennek a rövid cikknek a témájául választani.

\section{Hivatkozások}

[1] Bozóki, S., Csató, L. And Temesi, J.: An application of incomplete pairwise comparison matrices for ranking top tennis players, European Journal of Operational Research, Vol. 218 No. 1, pp. 211-218 (2016). DOI: 10.1016/j.ejor.2015.06.069

[2] Bozóki, S., Dezső, L., Poesz, A. And Temesi, J.: Analysis of pairwise comparison matrices: an empirical research, Annals of Operations Research, Vol. 211 No. 1, pp. 511528 (2013). DOI: 10.1007/s10479-013-1328-1

[3] BozÓKI, S. AND FüLÖP, J.: Efficient weight vectors from pairwise comparison matrices, European Journal of Operational Research, Vol. 264 No. 2, pp. 419-427 (2018). DOI: $10.1016 /$ j.ejor.2017.06.033

[4] BozóKI, S., FÜlÖP, J. AND RÓNYAI, L.: On optimal completions of incomplete pairwise comparison matrices, Mathematical and Computer Modelling, Vol. 52 No. 1-2, pp. 318-333 (2010). DOI: 10.1016/j.mcm.2010.02.047

[5] BozóKI, S., FüLÖP, J. And Poesz, A.: On reducing inconsistency of pairwise comparison matrices below an acceptance threshold, Central European Journal of Operations Research, Vol. 23 No. 4, pp. 849-866 (2015). DOI: 10.1007/s10100-014-0346-7

[6] BozÓKI S. AND RAPCSÁK T.: On Saaty's and Koczkodaj's inconsistencies of pairwise comparison matrices, Journal of Global Optimization, Vol. 42 No. 2, pp. 157-175 (2008). DOI: $10.1007 / \mathrm{s} 10898-007-9236-\mathrm{z}$

[7] Brunelli, M.: Introduction to the Analytic Hierarchy Process, Springer (2015) DOI: 10.1007/978-3-319-12502-2

[8] Brunelli, M.: A survey of inconsistency indices for pairwise comparisons, International Journal of General Systems, Vol. 47 No. 8, pp. 751-771 (2018). DOI: 10.1080/03081079.2018.1523156 
[9] Ehrgotт, M.: Multicriteria Optimization, Springer, (2005). DOI: 10.1007/3-540-27659-9

[10] Forgó, F. And Temesi, J.: Computer-aided licence selection Engineering Cost and Production Economics, Vol. 11 No. 3, pp. 161-170 (1987). DOI: 10.1016/0167-188X(87)90039-5

[11] Fülöp, J. And Temesi, J.: A Data Envelopment Analysis (DEA) alkalmazása ipari parkok hatékonyságának vizsgálatára, Szigma, XXXII. évf., 3-4.sz., pp. 85-110 (2001).

[12] GÁspár, L. AND Temesi, J.: Lineáris programozási gyakorlatok, Tankönyvkiadó, Budapest, (1987,1. kiadás, 2002, 5. kiadás)

[13] GÁspár, L. And Temesi, J.: Matematikai programozási gyakorlatok, Tankönyvkiadó, Budapest, (1989, 1. kiadás, 1999, 4. kiadás)

[14] Németh, S.Z., Rapcsák, T. And Temesi, J.: Evaluation of tenders for developing the economy, Central European Journal of Operations Research, Vol. 13 No. 3, pp. 299-317 (2005).

[15] Pór, A., Stahl, J. And Temesi, J.: Decision support system for production control: multiple criteria decision making in practice, Engineering Cost and Production Economics, Vol. 20 No. 2, pp. 213-218 (1990). DOI: 10.1016/0167-188X(90)90104-P

[16] SaAty, T.L.: The Analytic Hierarchy Process, New York, McGraw-Hill, (1980).

[17] Steuer, R.E.: Multiple Criteria Optimization: Theory, Computation and Application, New York, Wiley, DOI: 10.1002/oca.4660100109

[18] Temesi, J.: A döntéselmélet alapjai, Aula Kiadó, Budapest, (2002). https://www.worldcat.org/title/donteselmelet-alapjai/oclc/909532354

[19] Temesi, J.: Consistency of the decision-maker in pair-wise comparisons, International Journal of Management and Decision Making, Vol. 7 No. 2/3, pp. 267-274 (2006). DOI: 10.1504/IJMDM.2006.009148

[20] Temesi, J.: Pairwise comparison matrices and the error-free property of the decisionmaker, Central European Journal of Operations Research, Vol. 19 No. 2, pp. 239-249 (2011). DOI: 10.1007/s10100-010-0145-8

[21] Temesi, J.: An interactive approach to determine the elements of a pairwise comparison matrix, Central European Journal of Operations Research, Vol. 27 No. 2, pp. 533-549 (2019). DOI: 10.1007/s10100-018-0539-6

[22] Varró, Z. And Temesi, J.: Operációkutatás, Aula Kiadó, Budapest, 2007, Akadémiai Kiadó, (2014), (2017). DOI: 10.1556/9789630598699

[23] Yu, P.L.: A Class of Solutions for Group Decision Problems, Management Science, Vol. 19 No. 8, pp. 936-946 (1973). DOI: 10.1287/mnsc.19.8.936

[24] Yu, P.L. And Zeleny, M.: The Set of All Nondominated Solutions in Linear Cases and a Multicriteria Simplex Method, Journal of Mathematical Analysis and Applications, Vol. 49, pp. 430-468 (1975). DOI: 10.1016/0022-247X(75)90189-4 


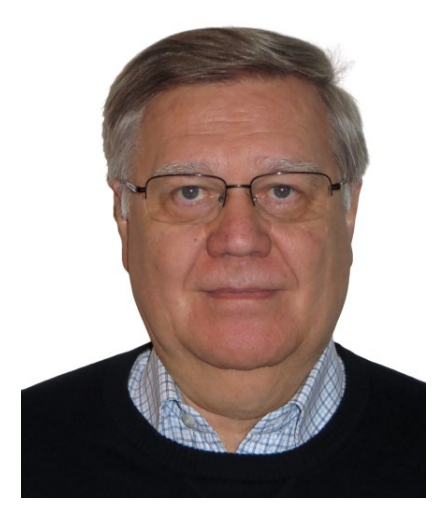

Temesi József 1950-ben született, egyetemi tanulmányait 1969 és 1974 között végezte a Marx Károly Közgazdaságtudományi Egyetem népgazdasági tervező-elemző szakán. 1974-től 2015-ig ennek az egyetemnek a Matematika Tanszékén és jogutódain dolgozott, 1997-től egyetemi tanárként, 2000 és 2014 között az Operációkutatás és Aktuáriustudományok Tanszék vezetőjeként. Jelenleg a Budapesti Corvinus Egyetem professor emeritusa. 1992-ben kandidátusi fokozatot szerzett a közgazdaságtudományok területén, 1998-ban habilitált. Több ciklusban és jelenleg is az MTA Operációkutatási Bizottság tagja. A Magyar Operációkutatási Társaság vezetőségi tagja, majd 2006 és 2008 között elnöke, a Gazdaságmodellezési Társaságnak elnökségi tagja, majd 2012 és 2015 között elnöke volt. A GMT közgazdasági-matematikai lapjának, a Szigmának 20 éven keresztül szerkesztője, szerkesztőbizottsági tagja. Az elmúlt 40 évben számos magyar és nemzetközi konferencia szervező bizottsági tagja, előadója. 1998-ban Széchenyi ösztöndíjat nyert el, 2006-ban a Magyar Köztársasági Érdemrend tisztikeresztjével tüntették ki. Szakmai díjai: Krekó Béla-díj (2017), Egerváry Jenő emlékplakett (2019). Kutatási és oktatási témái az operációkutatás és a döntéselmélet elméleti és alkalmazási területeihez kapcsolódnak, könyvei és cikkei ezekben a témákban jelentek meg magyar és angol nyelven. Az MTMT-ben az ide sorolható publikációk száma mintegy 100, az ezekre történt független hivatkozások száma 250 .

\title{
TEMESI JÓZSEF
}

Budapesti Corvinus Egyetem

Operációkutatás és Aktuáriustudományok Tanszék

1098 Budapest, Fővám tér 8.

jozsef.temesi@uni-corvinus.hu

\section{PAIWISE COMPARISONS FOR DECISION MAKING}

\author{
JózSEF TEMESI
}

Multi-attribute decision making problems have finite sets of alternatives and criteria. The goal is to derive a ranking of alternatives according to the criteria or to find the best alternative. The input of the decision problem is the decision matrix. This invited paper deals with a popular technique of generating a decision matrix, the method of pairwise comparisons. The aim of the short paper is to describe some properties of pairwise comparisons highlighting the explicit and implicit conditions of its application, and summarizing some results of the author in that field. The conclusion is that the interpretation of the results in real-life applications has to take into account both the advantages and drawbacks of the technique, and it is of utmost importance to involve the decision maker in the solution process.

Keywords: pairwise comparisons, multi-attribute decision making, interactive procedures. 